Extract from proceedings of Seminar on High Earthquake Risk Buildings. Note: This article is an amended version of that published in the proceedings.

\title{
THE NEED FOR A STRENGTHENING CODE
}

\section{B. C. Bluck*}

\section{INTRODUCTION}

Any discussion of Section 301A of the Municipal Corporations Act which has as its objective the production of a strengthening code to meet the requirements of the Act must first answer the specific question of why the Act defined a moderate earthquake as its design standard. Why do we halve our design loads when strengthening old buildings? To my mind there are two reasons :-

(1) That compulsory strengthening of buildings is only to be invoked to minimise the risk to life. Any standard that sought to protect property as well would be too high a standard. Property risk is a problem for the owner to assess - not the community.

(2) The probability, not only of an earthquake damaging a building but also damaging a building at the time it is occupied. It is as well to remember that Napier had not had a serious earthquake prior to 1931 and it has not had one since. The Act thus acknowledges that the earthquake risk is a probability rather than a certainty.

In applying the Act then, we should always remember that it is an Act designed to protect people - and is applied not only to buildings but indirectly to the people who own these buildings. In the case of some historic buildings those owners could be you and me - the community. We must avoid trying to protect property by means of this legislation. Property can only be protected by replacement with properly designed buildings - buildings designed to resist full earthquake load - not half earthquake loads.

\section{THE ACT}

The legal procedure we have adopted to safeguard the lives of those occupying buildings likely to be a hazard in an earthquake is the correct one. The Act states the legal requirement - STRENGTHEN. How to strengthen is the responsibility of the engineering profession. We must develop a Code which will assist the courts, owners and designers in their assessment of particular problems. Such a code must serve three purposes.

(a) State logical strengthening criteria which will allow an owner to understand the limitations of his own building.

(b) In the development of these criteria it should set guidelines which will allow the competent designer to create safe buildings.

(c) Give the Courts a basis on which its assessors can base consistent judgements.

\footnotetext{
* Staff Engineer, Christchurch City Council.
}

While the legal procedure is correct there must be some doubts about the actual wording of the Act. Administration and the development of a strengthening code would have been far simpler if the wording of the Act had been clearer. The concept of ultimate loadcapacity is related back to a standard building code which, except for the chapter on reinforced concrete and the new draft loading code is not written in a format which allows ultimate load capacity theory to be used. As most of the buildings likely to be affected by Section 301A are masonry buildings this is a serious limitation, even allowing for the fact that a revision of the masonry codes has started. Removal of all ambiguity from the wording of the Act must be the first priority if its powers are to be effectively implemented.

If the words "... will have its ultimate load capacity exceeded in a moderate earthquake ..." were replaced by the words "... wili have structural elements stressed to a greater extent than is allowed by recognised Building Codes when subjected to at least the seismic forces of a moderate earthquake ..." it would then be possible to develop a logical strengthening code which could use either elastic theory or ultimate load theory. To a certain extent this is playing with words but we must always remember that we are dealing with the Law - we have no right, as engineers, to ask for anything from an owner which the community does not authorise us to ask for in the Act. We must be legally correct as well as being reasonable in an engineering sense and section (8) of the Act reinforces the legal nature of the amendment: -

"The sole function of the assessors shall be to assist the court in determining the application and the application shall be determined by the Court alone."

In other words - if there are any legal doubts the owner quite rightly wins.

\section{A STRENGTHENING CODE}

To administer this legislation two distinct codes are necessary :-

(a) A Building Classification Code.

(b) A Building Strengthening Code.

The Ministry of Works has developed its own classification code and the New Zealand Society for Earthquake Engineering has published a similar code. While the Christchurch City Council does not have a formal classification code it has combined building age and pedestrian activity with subjective judgement and simple arithmetic 
to achieve a general policy relating to strengthening which appears to be acceptable to owners. The greatest need, however, has been a code which will explain to owners and their consultants the guidelines on which it is assumed the requirements of the Act are based (as it is worded at the moment).

This code must do two things:-

(a) It must define the principles to be used in determining the ultimate load capacity of a building and as a result establish whether or not the Act is applicable.

(b) Having determined that a building does require strengthening then the code should further define the philosophies to be adopted in strengthening the building.

To my mind the most important part of such a code is the first part - the part that determines whether or not strengthening is required. It is in this area that the legal battles will be fought, if they are to be fought. It is in this area that the Act talks blithely of "ultimate load capacity" and "unreinforced masonry" when in fact there are no readily available codes which can give us a reasonable guidance on how to assess the "ultimate load capacity" of an unreinforced masonry building.

The second part of the code which answers the question "how much strengthening" is less important. It will probably never be a legal problem. Economics will be the most critical factor. Some two years ago the Christchurch City Council prepared a draft code based on the loadings specified in Chapter 8, N.z.S. 1900 (1965). We recently attempted to revise that code and write it in terms of the new draft loading Code, N.Z.S. 4203. The result highlights the dangers of the Act ever being too specific on acceptable load levels. If an amendment to the Act made N.Z.S. 4203 the design standard, rather than Chapter 8, N.z.S. 1900 (1965) the arbitrary value of our "moderate earthquake" would increase from $58 \mathrm{~g}$. to some $168 \mathrm{~g}$. for the average 2 to 3 storey masonry building with load bearing shear walls. I would be surprised if this increase in design loading would significantly affect the safety of these buildings, it may reduce some property damage but that is a decision for the owner to make - not the community. To this extent the approach of Long Beach, California is interesting. Using what they call a "balanced risk" concept they have attempted to relate the probability of an earthquake of a certain size with building occupancy. The longer an owner wishes to retain a building the bigger the earthquake he has to design against. The major danger in having such an approach as part of the legal machinery is that we may tend to imagine that fancy arithmetic gives correct answers. Sound detailing and the correct design philosophy are of much greater significance than theoretical calculation. It is important therefore to ensure that any system we develop to remove the danger created by high earthquake risk buildings, clearly separates the legal and technical problems. (a) An Act which says "strengthen": no more-no less.

(b) A suitable code which can legally define whether or not strengthening is required.

The engineering involvement is :-

(a) A classification code to determine the possibility of required strengthening.

(b) A suitable code which can legally define the need to strengthen (as in (b) above.

(c) A philosophy to determine the desirable extent of strengthening.

(d) A code to determine the method of strengthening.

\section{SUMMARY}

(1) While it is agreed that any strengthening system must be "to the satisfaction of the council" the wording of sub-section (3) of Section 301A is sufficiently ambiguous to mean that there could be conflicting technical evidence presented to the court at the time when it is being decided whether or not a particular building does constitute a danger. Such conflict will do no good to the Art of Seismic Engineering and the possibility of conflict should be removed by amending the Act.

(2) There is a need for both a classification code which will allow all local authorities to assess whether or not they have buildings in their areas which could constitute a danger in a moderate earthquake and a strengthening code which will allow them to assess whether or not the strengthening proposed will remove the danger. Because the present New Zealand standards relating to buildings are undergoing a change of format this strengthening code will only be useful if it is a selfsufficient code.

(3) In developing any amendments to the Act or writing any codes which explain how to comply with the requirements of the Act we must remember that the reason the Act was written was to save lives. Strengthening is not required to protect property and most of all we don't want to prolong the life of unsuitable buildings by unnecessary strengthening. There is a case for ensuring that some historic buildings be retained in a safe state but in considering such buildings we must ensure that safety in a moderate earthquake is the design criteria. No cracks in a catastrophic earthquake is not the criteria envisaged by those writing the Act. If that had been the criteria they would not have defined the moderate earthquake.

\section{ACKNOWLEDGEMENT}

The Author gratefully acknowledges the permission received from the City Engineer of the Christchurch City Council to participate in this Seminar and the assistance received from staff members in preparing the material which has been presented. 